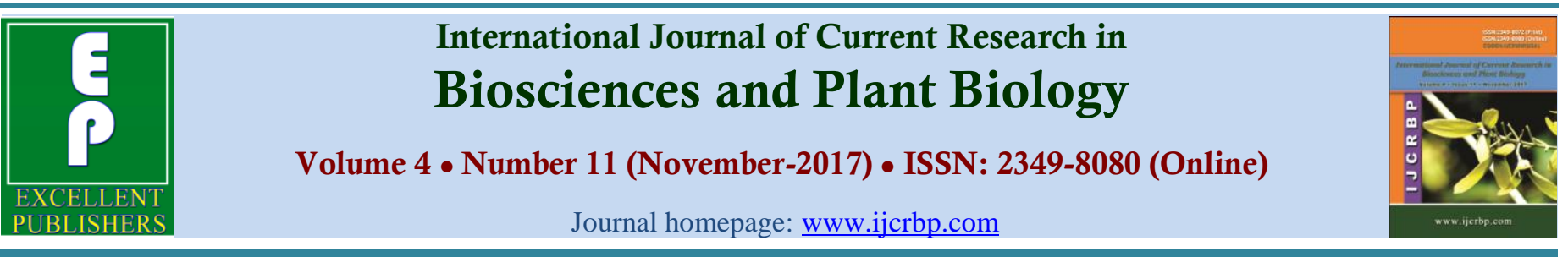

\title{
Mycotoxins in Food: Evaluation of Aflatoxin B1 and Ochratoxin A in a Few Foodstuffs in Côte D'Ivoire
}

\author{
Ehouman Ano Guy Serge ${ }^{1}$, Yao N’Zue Benjamin ${ }^{1 *}$, Hampoh Ade Hortense ${ }^{2}$, Fofana Alimata ${ }^{3}$, Traore \\ Karim Sory ${ }^{2}$ and Tano Kablan ${ }^{2}$
}

${ }^{1}$ Universite Jean Lorougnon Guede, BP 150 Daloa (Côte D'Ivoire)
${ }^{2}$ Universite Nangui Abrogoua, O2 BP 801 Abidjan 02, Abidjan (Côte D'Ivoire)
${ }^{3}$ centre Ivoirien Anti-Pollution (Ciapol), Abidjan (Côte D'Ivoire)

*Corresponding author.

\begin{tabular}{|c|c|}
\hline Abstract & Article Info \\
\hline \multirow{3}{*}{$\begin{array}{l}\text { The objective of this work was to determine the occurrence of mycotoxins like aflatoxin } \\
\text { B1and ochratoxin A in a few foodstuffs consumed by the Ivorian population. The levels of } \\
\text { AFB1 are higher than the contents of OTA. Dry gumbo is the most contaminated food in } \\
\text { AFB1 with an average grade of } 71.18 \mu \mathrm{g} / \mathrm{kg} \text {. Adjovan has an average AFB1 concentration } \\
\text { of } 64.65 \mu \mathrm{g} / \mathrm{kg} \text {. The levels of AFB1 of cassava are on average } 4.17 \mu \mathrm{g} / \mathrm{kg} \text {. Dried maize is } \\
\text { the least contaminated commodity with an average concentration of } 2.28 \mu \mathrm{g} / \mathrm{kg} \text {. The mean } \\
\text { levels of Aflatoxin B1 in the range of } 4.17 \text { to } 71.18 \mu \mathrm{g}^{-1} \cdot \mathrm{kg}^{-1} \text { exceed the maximum residue } \\
\text { limit (MRL) of } 2 \mu \mathrm{g} / \mathrm{kg} \text { for cereals and vegetables and } 5 \mu \mathrm{g} / \mathrm{kg} \text { for spices. The most } \\
\text { contaminated samples of ochratoxin A (OTA) samples were dry cassava and adjovan with } \\
\text { average concentrations of } 0.94 \mu \mathrm{g} / \mathrm{kg} \text { and } 0.92 \mu \mathrm{g} / \mathrm{kg} \text {. Low levels are } 0.60 \mu \mathrm{g} / \mathrm{kg} \text { and } 0.48 \\
\mu \mathrm{g} / \mathrm{kg} \text { respectively for dry gumbo and dry maize. These mean OT A values of the samples } \\
\text { analyzed are well below the maximum residue limit (MRL) of } 5 \mu \mathrm{g} / \mathrm{kg} \text { for vegetables, } \\
\text { cereals and spices. This study presents the results concerning the safety assessment of a } \\
\text { few foodstuffs regarding mycotoxins in Côte d'Ivoire. }\end{array}$} & $\begin{array}{l}\text { Accepted: } 12 \text { October } 2017 \\
\text { Available Online: 06 November } 2017\end{array}$ \\
\hline & Keywords \\
\hline & $\begin{array}{l}\text { Aflatoxin B1 } \\
\text { Foodstuffs } \\
\text { Mycotoxins } \\
\text { Ochratoxin A }\end{array}$ \\
\hline
\end{tabular}

\section{Introduction}

The word mycotoxin is derived from the Greek word 'mykes' meaning 'fungus' and the Latin word 'toxicum' meaning 'poison'. They are low molecular weight molecules produced as secondary metabolites by saprophytic fungi, especially Aspergillus, Penicillium and Fusarium (Aiko and Mehta, 2015). Mycotoxins are natural products, synthesized by fungi, capable of causing a toxic response when entering naturally (ingestion, inhalation or absorption through the skin) in animals or the human body (Bennett, 1987). According to the World Health Organization, $25 \%$ of the foodstuffs are contaminated with mycotoxins, which are responsible for significant economic losses (Mannon and Johnson, 1985). Good agricultural practices, plant disease management, and adequate storage conditions limit mycotoxin levels in the food chain yet do not eliminate mycotoxins completely. Aflatoxins, fumonisins, ochratoxin A, zearalenone and deoxynivalenol are mycotoxins that are detected in cereal crops (Ezekiel et al., 2014; Warth et al., 2012; 
Juan et al., 2014; Zinedine and Idrissi, 2007) and in peanuts (Afolabi et al., 2015). Among dangerous mycotoxins, aflatoxins (AFs) and ochratoxin A (OTA) represent the greatest health risk in tropical Africa (Manjula et al., 2009), in Asia (Li et al., 2014) and the rest of the world (Alborch et al., 2012) due to their high toxicity. They are known to be carcinogenic, genotoxic, teratogenic, nephrotoxic, hepatotoxic and immunotoxic for humans (Creppy, 2002; Mahmoudi et al., 2012). Aflatoxins and ochratoxin A were classified in carcinogenic group 1 and $2 \mathrm{~B}$, respectively, by the International Agency for Research on Cancer in 1993 (IARC, 1993). Among aflatoxins, aflatoxin B1 (AFB1) is the most toxic form for mammals and causes damages such as toxic hepatitis, hemorrhage, edema, immunosuppression and hepatic carcinoma (Speijers and Speijers, 2004). In fact, various epidemiological studies have implicated the AFs and OTA in the increased incidence of gastrointestinal and liver cancer in Africa, Philippines and China (Zinedine and Idrissi, 2007). Recently, cases of acute poisoning affecting a large geographic area in Kenya causing many deaths were reported by Centers for Disease Control and Prevention
(CDC, 2004). In Côte d'Ivoire, drying of foodstuffs takes place on the ground, along roads, on mats, on plastic films, on flat rocks, on the roofs of dwellings. The purpose of drying is to greatly reduce the various reactions involved in the normal decomposition of the product. But the drying and fermentation of foodstuffs may be subject to the proliferation of molds producing mycotoxins (CTA, 2008). For this reason, this study aims to draw the attention of the ivorian population to the existence of mycotoxins (ochratoxin A and aflatoxin B1) in dried or fermented foodstuffs consumed by populations. Specifically, it will be necessary to identify and quantify the mycotoxins likely to be present in these foodstuffs consumed by the ivorian population.

\section{Materials and methods}

\section{Biological materials}

Mycotoxins (aflatoxin B1 and ochratoxin A) were searched in dry maize, dry Gumbo, dry cassava (chips) and fermented fish (adjovan) samples (Figs. 1a, 1b, 1c and 1d).

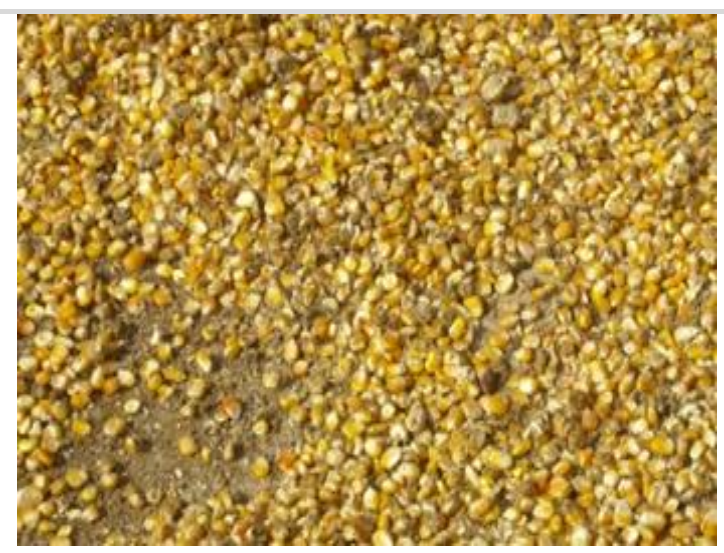

(a)

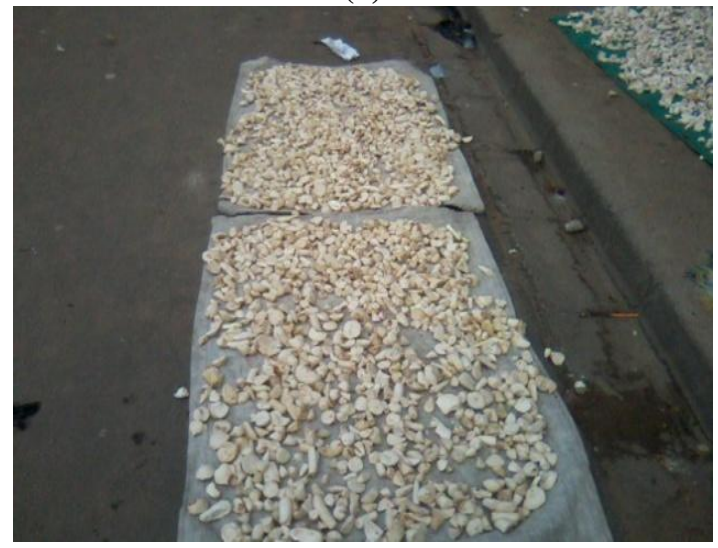

(c)

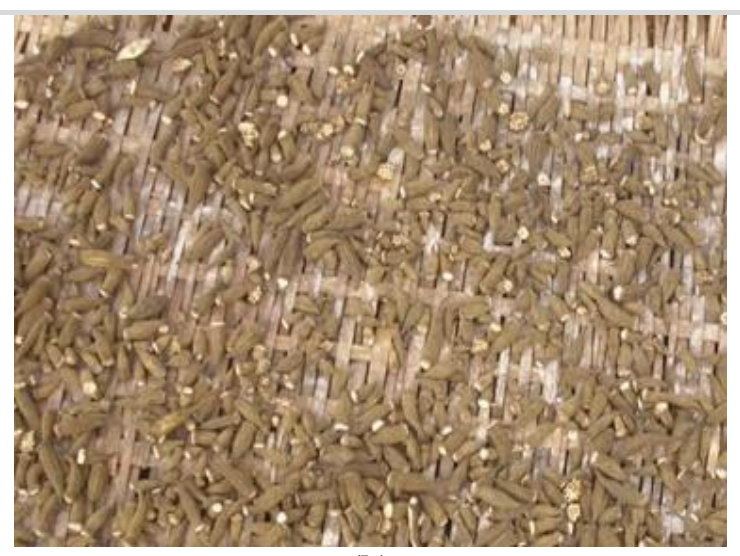

(b)

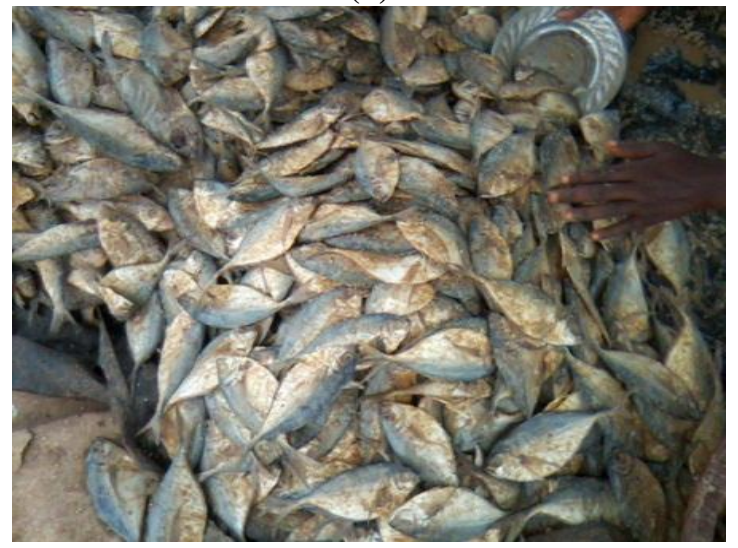

(d)

Fig. 1: Foodstuffs (a) Dry maize ; (b) Dry gumbo ; (c) Dry cassava ; (d) Fermented fish (Adjovan). 


\section{Methods}

Sampling : Dried cassava, dried maize and dried Gumbo samples were collected from Abobo (Abidjan, Côte d'Ivoire) at the main market. Adjovan samples were taken from the commune of Port-Bouët (Abidjan, Côte d'Ivoire).

\section{Methods of preparation and extraction of mycotoxins}

General principle: Whatever the material used (dry maize, dry gumbo, dry cassava and adjovan), the principle of the technique is based on an acidified chloroform extraction in the presence of magnesium chloride. The mycotoxins are extracted under acidic conditions from the samples of the crushed matrices. The acidification and the ionic strength of the extraction solution make it possible to partly break the bonds of the toxins to the constituents of the matrix and thus promote their extraction. The purification of the extract is carried out by phase sharing. The mycotoxins are soluble, sometimes in the aqueous phase, sometimes in the organic phase depending on their ionization state.

Preparation of standard toxin solutions: The powdered mycotoxins (OTA, AF) are solubilized in ultra pure methanol. One (1) $\mathrm{mg}$ of toxin is weighed on the precision balance and dissolved in $1 \mathrm{~mL}$ of solvent. For OTA this stock solution is diluted one hundred times and the concentration of the diluted solution is determined precisely by assaying the absorbance to the spectrophotometer according to the following parameters:

- For OTA $\left(\mathrm{PM}=403.8 \mathrm{~g}^{-1} \cdot \mathrm{mole}^{-1}\right)$ : Absorbance measurement at $330 \mathrm{~nm}$. At this wavelength, the molar absorption coefficient of Ochratoxin A in methanol is $5500 \mathrm{~mol}^{-1} \mathrm{~cm}^{-1}$.

- For AF: Measurement of the absorbance at $360 \mathrm{~nm}$, the molar absorption coefficient in methanol $\varepsilon$ is 21800 $\mathrm{mol}^{-1} \mathrm{~cm}^{-1}$.

Extraction of mycotoxins from different food matrices: The samples were analyzed by the method developed by Molinié et al. (2005). The extraction is carried out in an acid medium and the purification is carried out by liquid-liquid partition, in order to allow the simultaneous extraction of the OTA and AFB1, and to defect the mycotoxins from their binding with proteins. fifty (50) $\mathrm{g}$ of each matrix (dry maize, dry gumbo, dry cassava and adjovan) finely ground are mixed with $400 \mathrm{~mL}$ of extraction solvent composed of acetonitrile/water (9:1). The water contains $4 \%$ of potassium chloride and $0.8 \mathrm{~mL}$ of concentrated sulfuric acid. The mixture is placed in a $500 \mathrm{ml}$ Erlenmeyer flask and placed on a rotary shaker for 20 minutes. The extract is filtered under vacuum on filter paper (Wattman No. 4). After filtration, an aliquot of $200 \mathrm{~mL}$ of this filtrate is defatted twice, by adding $100 \mathrm{~mL}$ of $\mathrm{n}$ hexane. The defatted filtrate is placed in a separatory funnel for one minute. The lower phase is recovered in a $250 \mathrm{~mL}$ Erlenmeyer flask. The mycotoxins are extracted with $100 \mathrm{~mL}$ of chloroform from the lower acetonitrile/water phase to which $50 \mathrm{~mL}$ of ultra pure water have been added. The mixture of acetonitrile/water and chloroform is mechanically stirred. After a decantation of 10 minutes, the chloroform phase (lower) is recovered in an Erlenmeyer flask. The acetonitrile/water phase (upper phase) is added twice with $20 \mathrm{ml}$ of chloroform. After stirring for 10 minutes and decanting also for 10 minutes, the chloroform phase capable of containing the mycotoxins is recovered. At the end of these three extractions, the mycotoxins dissolved in the chloroform fractions are extracted three times by the addition of $50 \mathrm{ml}$ of a $5 \%$ sodium bicarbonate solution. After stirring (10 minutes) and decantation (10 minutes), the upper bicarbonate phase containing the mycotoxins is recovered. At the end of the three extractions with bicarbonate, all the bicarbonate fractions are combined in the same Erlenmeyer flask.

The extract is acidified to $\mathrm{pH} 1.5$ by the addition of concentrated hydrochloric acid. Finally mycotoxins are extracted from this mixture three times with chloroform (volumes of 100, 50 and $50 \mathrm{~mL}$ ) after stirring (10; 5 and 5 minutes) and decantation (10 minutes at each extraction step). The chloroform extract (lower phase) containing the mycotoxins is recovered in an Erlenmeyer flask. The whole of the combined chloroform extracts are evaporated (under vacuum) with a rotavapor at $45{ }^{\circ} \mathrm{C}$. The volume of chloroform is reduced to about $1 \mathrm{~mL}$. The dry extract is taken up with $1 \mathrm{ml}$ of methanol and placed in an ultrasonic bath for one minute. When the resuspension is complete, this $\mathrm{mL}$ of methanol is filtered over a $0.2 \mu \mathrm{m}$ filter previously conditioned with methanol, that is to say that the filter is rinsed with $500 \mu \mathrm{L}$ of methanol. The filtered methanol is placed in a hemolysis tube and the filtrate is dried in a water bath under a nitrogen stream to recover the mycotoxins. After drying, the extract resuspended in 500 $\mu \mathrm{L}$ of methanol is placed in a glass flask, stored at $-20{ }^{\circ} \mathrm{C}$ before being analyzed by HPLC. 


\section{Chromatographic analysis (HPLC) of mycotoxins}

High Performance Liquid Phase Chromatography (HPLC) allowed the separation of the various compounds contained in the mixture in order to characterize and quantify them. The detection and quantification of the OTA was carried out by fluorimetric detection. The reading was done by a fluorodensitometry reader. Thus, the fluorimetric detector had an excitation wavelength of $333 \mathrm{~nm}$ and an emission wavelength of $460 \mathrm{~nm}$. Confirmation of the presence of aflatoxins in the sample by HPLC requires derivatization of aflatoxins B1 and G1. This is necessary in order to increase their natural fluorescence under UV light, and thus be able to detect them better. Aflatoxin B1 was detected at wavelengths of excitation at $362 \mathrm{~nm}$ and emission filters at $425 \mathrm{~nm}$.

The mobile phase A was water-methanol $(55: 45 ; \mathrm{v} / \mathrm{v})$, $119 \mathrm{mg}$ of potassium bromide and $350 \mathrm{~mL}$ of nitric acid and the mobile phase B was water-methanol (20:80; v/v), $119 \mathrm{mg}$ of potassium bromide and 350 $\mathrm{mL}$ of nitric acid. AFs and OTA standard solutions were used for the construction of a five-point calibration curve of peak areas versus concentration (ng/mL). The operating conditions were as follows: injection volume of $100 \mathrm{~m} \mathrm{~L}$ of sample and standard solutions; C18 reverse-phase HPLC column, Uptisphere type, ODS, $5 \mu \mathrm{m}$ particle size, 5 ODB, $250 \times 4.6 \mathrm{~mm}$, with identical pre-column, thermo- statically controlled at $40{ }^{\circ} \mathrm{C}$; isocratic flow rate of 0.8 $\mathrm{mL} / \mathrm{min}$. Mobile phase gradient: mobile phase A: $0 \%$ (0-26 min); $65 \%$ (26-45 min); $0 \%$ (45-50 min); 41 $\%(20-25)$. The detection and quantification limits on aflatoxins were $0.3 \mu \mathrm{g} / \mathrm{kg}$ and $1 \mu \mathrm{g} / \mathrm{kg}$, respectively.

The detection and quantification limits on ochratoxin A were $0.05 \mu \mathrm{g} / \mathrm{kg}$ and $0.1 \mu \mathrm{g} / \mathrm{kg}$, respectively. The contents were calculated from a calibration curve established with aflatoxins (TSL-108, Biopharm Rhône Ltd, Glasgow, UK) and ochratoxin standards (TSL-504, Biopharm Rhône Ltd, Glasgow, UK).

\section{Statistical analysis}

The statistical analysis was performed on the results using SPSS (version 10.0) software. The comparison of the variables measured during this study was done using the analysis of variance (ANOVA) and Duncan test. The differences were considered significant if $p \leq 0.05$. All the experiments were conducted in triplicate.

\section{Results and discussion}

The results showed that samples of dried cassava, dried maize, dried gumbo and adjovan harvested in the communes of Abobo and Port Bouet contained mycotoxins (Aflatoxin B1 and Ochratoxin A) at different concentrations. The levels of AFB1 are higher than the contents of OTA (Fig. 2).

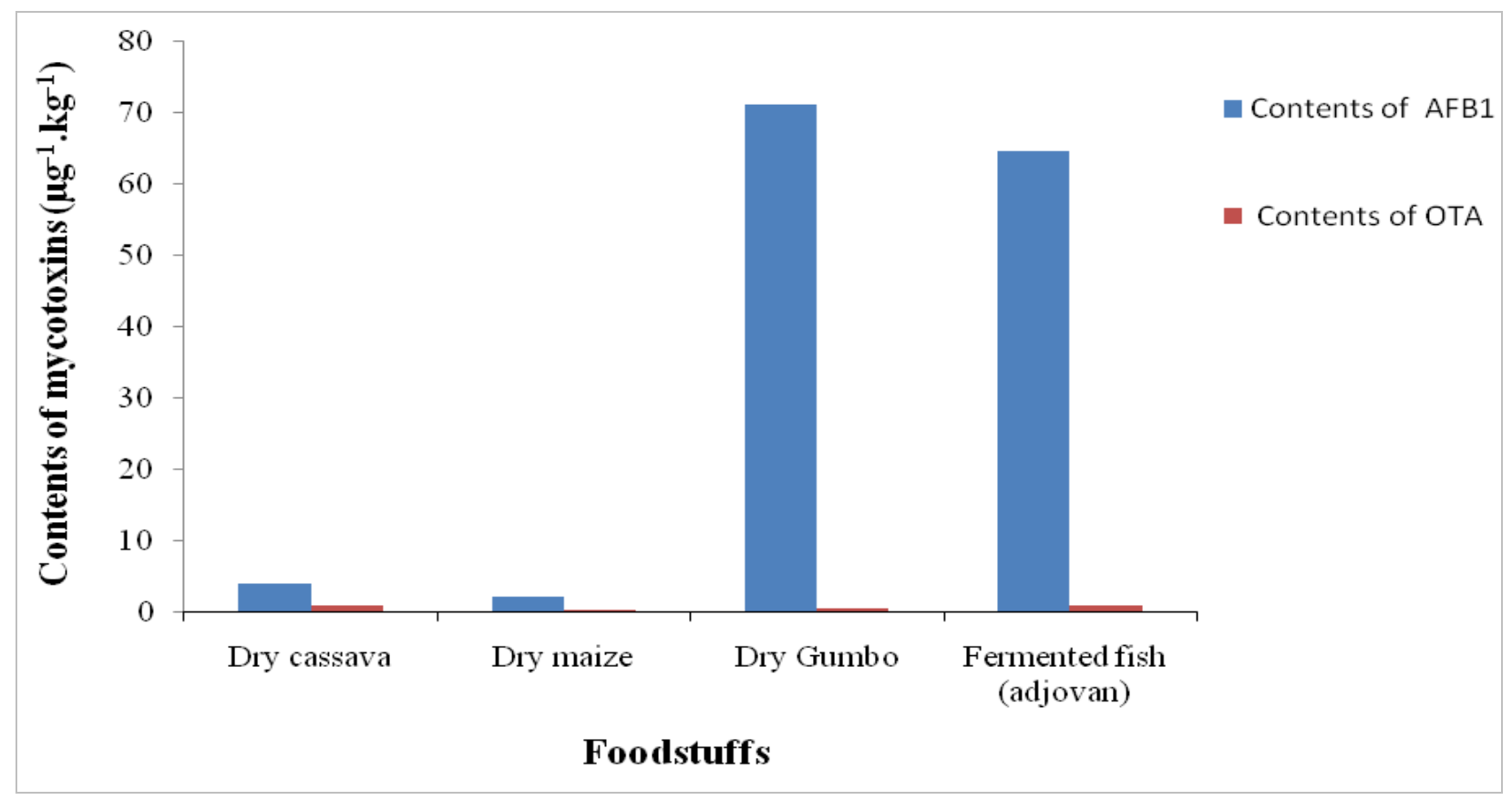

Fig. 2: Contents of AFB1 and OTA in foodstuffs. 
Several authors have established that AFs have been detected in various commodities such as maize, wheat, barley, nuts, cocoa, dried fruits, wines and spices and other foodstuffs (Juan et al., 2014; Se and Nadir, 2003). OTA contaminates cereals such as barley, wheat, maize, oat, as well as green coffee, fruit juices (grape fruit), wines and spices (Juan et al., 2014; Zinedine and Idrissi, 2007). However, environmental factors which effect mold growth and mycotoxin production are temperature, $\mathrm{pH}$, moisture content, oxygen levels, nutritional components, the mold strains and microbial competition (Jackson and Al-Taher, 2008). This explains the fact that the levels of AFB1 are higher than the contents of OTA. Dry gumbo is the most contaminated food in AFB1 with an average grade of $71.18 \mu \mathrm{g} / \mathrm{kg}$ (Table 1).

Table 1. AFB1 and OTA content in dried gumbo.

\begin{tabular}{lll}
\hline Samples & $\begin{array}{l}\mathbf{A F B 1} \\
\left(\boldsymbol{\mu g}^{-1} \cdot \mathbf{k g}^{-\mathbf{1}}\right)\end{array}$ & $\begin{array}{l}\mathbf{O T A} \\
\left(\boldsymbol{\mu g}^{-1} \cdot \mathbf{k g}^{-\mathbf{1}}\right)\end{array}$ \\
\hline 1 & 160 & 0.59 \\
2 & 49.6 & 0.57 \\
3 & 156 & 0.68 \\
4 & 70.6 & 0.71 \\
5 & 48.7 & 0.59 \\
6 & 89.4 & 0.64 \\
7 & 48.4 & $n d$ \\
8 & 50.1 & 0.54 \\
9 & 41.2 & $n d$ \\
10 & 37.8 & 0.51 \\
11 & 31.2 & $n d$ \\
Total average concentration & $\mathbf{7 1 . 1 8}$ & $\mathbf{0 . 6 0}$ \\
$\left(\mu \mathrm{g}^{-1} \cdot \mathrm{kg}^{-1}\right)$ & & \\
\hline nd: not detected & &
\end{tabular}

Table 2. AFB1 and OTA content in Adjovan.

\begin{tabular}{lll}
\hline Samples & $\begin{array}{l}\mathbf{A F B 1} \\
\left(\mathbf{\mu g}^{-\mathbf{1}} \cdot \mathbf{k g}^{-\mathbf{1}}\right)\end{array}$ & $\begin{array}{l}\mathbf{O T A} \\
\left(\boldsymbol{\mu g}^{-\mathbf{1}} \mathbf{k g}^{-\mathbf{1}}\right)\end{array}$ \\
\hline 1 & 104 & 0.48 \\
2 & 56.7 & 1.23 \\
3 & 43.8 & nd \\
4 & 53.7 & 0.31 \\
5 & 89.5 & 1.32 \\
6 & 42.7 & nd \\
7 & 48.2 & nd \\
8 & 87.4 & 1.48 \\
9 & 71.2 & 0.72 \\
10 & 49.3 & nd \\
Total average concentration & $\mathbf{6 4 . 6 5}$ & $\mathbf{0 . 9 2}$ \\
$\left(\boldsymbol{\mu g}^{-1} \cdot \mathrm{kg}^{-1}\right)$ & & \\
\hline nd: not detected. & &
\end{tabular}

Indeed, the high contamination of dry gumbo can be explained by the fact that gumbo is dried in its entirety (high humidity). It dries hard because the sun's rays will take time to reach the interior and the food is prone to the proliferation of aflatoxin B1 producing molds. Sliced gumbo dries generally faster than whole food, but slices should be no more than $1 \mathrm{~cm}$ thick to dry completely and quickly to prevent mycotoxin proliferation (FAO, 2002). Adjovan has an average AFB1 concentration of $64.65 \mu \mathrm{g} / \mathrm{kg}$ (Table 2). Yet before being dried the adjovan fish underwent a salting which prevents the microbial proliferation by decrease of the water of the product. It is thus protected from the ambient air by this envelope of salt. But the samples of adjovan could be contaminated with AFB1 when drying by the materials used, ambient air, rodents or even the geographical location (industrial zone). Indeed, the place of drying of the adjovan is near a garbage dump and stagnant water which are vectors of contamination of mycotoxins (Brochard and le Bâcle, 2009). The levels of AFB1 of cassava are on average $4.17 \mu \mathrm{g} / \mathrm{kg}$ (Table 3 ).

Table 3. AFB1 and OTA content in dry casava.

\begin{tabular}{lll}
\hline Samples & $\begin{array}{l}\text { AFB1 } \\
\left(\boldsymbol{\mu g}^{-1} \cdot \mathbf{k g}^{-\mathbf{1}}\right)\end{array}$ & $\begin{array}{l}\text { OTA } \\
\left(\boldsymbol{\mu g}^{-1} \cdot \mathbf{k g}^{-\mathbf{1}}\right)\end{array}$ \\
\hline 1 & 29.82 & 2.36 \\
2 & 4.44 & 0.35 \\
3 & 12.43 & 0.87 \\
4 & 0.65 & 0.29 \\
5 & 0.75 & nd \\
6 & 1.34 & 0.42 \\
7 & 2.33 & 1.63 \\
8 & 0.89 & 0.29 \\
9 & 1.25 & 0.87 \\
10 & 1.44 & 2.78 \\
11 & 1.21 & 0.38 \\
12 & 0.87 & nd \\
13 & 0.58 & nd \\
14 & nd & 0.12 \\
15 & 0.02 & nd \\
16 & 0.43 & nd \\
Total average concentration & $\mathbf{4 . 1 7}$ & $\mathbf{0 . 9 4}$ \\
$\left(\mu g^{-1} \cdot\right.$ kg $\left.^{-1}\right)$ & & \\
\hline nd: not detected. & &
\end{tabular}

Dried maize is the least contaminated commodity with an average concentration of $2.28 \mu \mathrm{g} / \mathrm{kg}$ (Table 4). Dried cassava $(4.17 \mu \mathrm{g} / \mathrm{kg})$ and dried maize $(2.28 \mu \mathrm{g} / \mathrm{kg})$ can be derived from the conditions under which they were harvested, dried and stored. According to Ilhame and Aziz (2006), mycotoxin contamination of food can occur during harvest and storage. Indeed, if the food is not well dried or rainfall occurs during drying, the high humidity may favor the proliferation of mycotoxins. Fluoxins are produced by the Aspergillii; Particularly 
favored mushrooms in a hot and humid environment. Aflatoxin production by Aspergillii occurs at high humidity (above 0.7 ) and temperatures sometimes above $30^{\circ} \mathrm{C}$ (Ilhame and Aziz, 2006). These factors may also explain high levels of Aflatoxin B1 in the samples because Côte d'Ivoire is in a tropical humid climate; Where temperatures sometimes exceed $30^{\circ} \mathrm{C}$ and relative humidity is high (Rougerie, 1978).

Table 4. AFB1 and OTA content in dry maize.

\begin{tabular}{lll}
\hline Samples & $\begin{array}{l}\text { AFB1 } \\
\left(\boldsymbol{\mu g}^{-\mathbf{1}} \mathbf{k g}^{-\mathbf{1}}\right)\end{array}$ & $\begin{array}{l}\text { OTA } \\
\left(\boldsymbol{\mu g}^{-\mathbf{1}} \mathbf{k g}^{-\mathbf{1}}\right)\end{array}$ \\
\hline 1 & 3.31 & 1.02 \\
2 & 0.75 & 0.12 \\
3 & 10.08 & nd \\
4 & 1.77 & nd \\
5 & 4.5 & nd \\
6 & 0.58 & 0.35 \\
7 & 1.34 & 1.03 \\
8 & 0.95 & 0.29 \\
9 & 0.89 & 0.85 \\
10 & 2.31 & nd \\
11 & 0.96 & 0.49 \\
12 & nd & 0.22 \\
13 & nd & 0.31 \\
Total average concentration $\left.^{-1} \mathrm{~kg}^{-1}\right)$ & $\mathbf{2 . 2 8}$ & $\mathbf{0 . 4 8}$ \\
\hline
\end{tabular}

nd: not detected.

Also, in Côte d'Ivoire drying is usually done in the open air (on the ground, in the yard, at the roadside, etc.) and therefore within the reach of dust or animal dirt. In addition, foods are naturally in contact with fungal spores before, during and after harvest, during transport and storage. Rodents, birds, insects and mites etc. Are involved in the contamination process by causing physical damage to plant tissues that promote spore penetration and mycotoxin production (Le Bars and Le Bars, 1982).

The mean levels of Aflatoxin B1 in the range of 4.17 to $71.18 \mu \mathrm{g}^{-1} \cdot \mathrm{kg}^{-1}$ (Table 5) exceed the maximum residue limit (MRL) of $2 \mu \mathrm{g} / \mathrm{kg}$ for cereals and vegetables and 5 $\mu \mathrm{g} / \mathrm{kg}$ for spices (EC, 2001; 2002). Their consumption therefore poses a risk to human and animal health because AFB1 is carcinogenic to our organs and especially the liver (Lovelace and Aalbersbekg, 1989). A relationship between the consumption of foods contaminated by these molds and the development of liver cancer has been established (Shank et al., 1972).

The most contaminated samples of ochratoxin A (OTA) samples were dry cassava and adjovan with average concentrations of $0.94 \mu \mathrm{g} / \mathrm{kg}$ (Table 2) and $0.92 \mu \mathrm{g} / \mathrm{kg}$ (Table 3). Low levels are $0.60 \mu \mathrm{g} / \mathrm{kg}$ (Table 1) and $0.48 \mu \mathrm{g} / \mathrm{kg}$ (Table 4) respectively for dry gumbo and dry maize. These mean OTA values of the samples analyzed are well below the maximum residue limit (MRL) of $5 \mu \mathrm{g} / \mathrm{kg}$ for vegetables, cereals and spices (EC, 2001; 2002). The OTA samples can be explained by the fact that the average temperatures in Côte d'Ivoire revolve around $28^{\circ} \mathrm{C}$ (Rougerie, 1978). This promotes the proliferation of molds producing OTA. Cereal-based food products such as maize sometimes contain ochratoxin A, and the amounts found are generally low. Families of Aspergillus and Penicillium mostly proliferate on the surface of grains (Ngundi et al., 2006). Thus, the drying could greatly reduce the water content of the samples analyzed; this has slowed down the proliferation of molds producing OTA. Even if the levels of these OTA samples are below the maximum residual limits, low OTA accumulation in the body can be toxic in the long term. These contents can be reduced if the foodstuffs are dried and stored under hygienic conditions.

Table 5. Comparison of the levels of foodstuffs in AFB1 and OTA with standards (CE, 2001; 2002).

\begin{tabular}{lllllllll}
\hline & \multicolumn{2}{l}{ Dry casava } & \multicolumn{2}{l}{ Dry maize } & \multicolumn{2}{l}{ Dry gumbo } & \multicolumn{2}{l}{ Adjovan } \\
\cline { 2 - 9 } & AFB1 & OTA & AFB1 & OTA & AFB1 & OTA & AFB1 & OTA \\
\hline Total average concentration $\left(\mu \mathrm{g}^{-1} \cdot \mathrm{kg}^{-1}\right)$ & 4.17 & 0.94 & 2.28 & 0.48 & 71.18 & 0.60 & 64.65 & 0.92 \\
Standard $\left(\mu \mathrm{g}^{-1} \cdot \mathrm{kg}^{-1}\right)$ & 2 & 5 & 2 & 5 & 2 & 5 & 5 & 5 \\
\hline
\end{tabular}

\section{Conclusion}

Analysis of our samples of dried gumbo, dried cassava, fermented fish (adjovan) and dry maize showed that AFB1 and OTA producing molds develop in our foods in Côte d'Ivoire. These molds proliferate in conditions of humidity and temperature which are favorable to them and produce mycotoxins which have toxic and even carcinogenic effects on the health of humans and animals. Aflatoxin B1 is the most toxic of aflatoxins while ochratoxin $\mathrm{A}$ is the most toxic of ochratoxins. The average concentrations of our samples are very high in 
AFB1 and largely exceed the MRLs. These samples contain levels no less negligible in OTA. Knowing that these mycotoxins are carcinogenic; it would be time to worry about the drying and storage conditions of these foodstuffs in order to reduce the proliferation of mycotoxigenic molds. Awareness of the population and especially the rural world must be made on the methods of harvesting, drying and preserving foodstuffs. This study aims to draw the attention of the ivorian population to the existence of mycotoxins (ochratoxin A and aflatoxin B1) in dried or fermented foodstuffs consumed by populations.

\section{Conflict of interest statement}

Authors declare that they have no conflict of interest.

\section{References}

Afolabi, C. G., Ezekiel, C. N., Kehinde, I. A., Olaolu1, A. W., Ogunsanya, O. M., 2015. Contamination of groundnut in South-Western Nigeria by aflatoxigenic fungi and aflatoxins in relation to processing. J. Phytopathol. 163, 279-286.

Aiko, V., Mehta, A., 2015. Occurrence, detection and detoxification of mycotoxins. J. Biosci. 40, 943-954.

Alborch, L., Bragulat, M. R., Castella, G., Abarca, M. L., Cabanes, F. J., 2012. Mycobiota and mycotoxins contamination of maize flours and popcorn kernels for human consumption commercialized in Spain. Food Microbiol. 32, 97-103.

Bennett, J.W., 1987. Mycotoxins, mycotoxicoses, mycotoxicology and Mycopathologia. Mycopathol. 100 (1), 3-5.

Brochard, G., le Bâcle, C., 2009. Département étude et assistance médicale INRS. Mycotoxine en milieu de travail: origine propriété toxique des principales mycotoxines. 25P.

CDC, Centers for Disease Control and Prevention, 2004. Outbreak of aflatoxins poisoning eastern and central provinces, Kenya, January-July (2004). Morbidity and Mortality Weekly Report 3 pp. 790-793.

Creppy, E. E., 2002. Update of survey, regulation and toxic effects of mycotoxins in Europe. Toxicol. Lett. $127,19-28$.

CTA, 2008. Le séchage des produits agricoles. Postbus 380, 6700 A J Wageningen, Pays Bas Tél (31) (0) $\begin{array}{lllllll}317 & 467100 & \text { Fax } & (31) & \text { (0) } & 317 & 460067\end{array}$ http://www.cta.int.

EC, 2001. Teneurs maximales en aflatoxines et en OTA dans quelques denrées alimentaires. J. Officiel L77 du 16.3.2001, 20 p.

EC, 2002. Teneurs maximales en aflatoxines et en OTA dans quelques denrées alimentaires. Commission du 12 mars 2002 fixant des teneurs maximales pour certains contaminants dans les denrées alimentaires. pp.1-3.

Ezekiel, C.N. I.E., Udom, J.C., Frisvad, M.C., Adetunji, J., Houbraken, S.O., Fapohunda, R.A., Samson, O.O., Atanda, M.C., Agi-Otto., Onashile, O.A., 2014. Assessment of aflatoxigenic Aspergillus and other fungi in millet and sesame from Plateau State, Nigeria. Mycol. 5(1), 16-22.

FAO, 2002. Département de l'agriculture. Améliorer la nutrition grâce au jardin potager Rubrique technologique du jardinage 18: Traitement, conservation et stockage. 6p.

IARC (International Agency for Research on Cancer), 1993. Monographs on the evaluation of carcinogenic risks to humans. In: Some naturally occurring substances: Food items and constituents, heterocyclic aromatic amines and mycotoxins. International Agency for Research on Cancer, 56, 489-521.

Ilhame, B., Aziz, A., 2006. Aflatoxine: Toxine redoutable dans nos aliments. 5p.

Jackson, L.S., Al-Taher, F., 2008. Factors affecting mycotoxin production in fruits. In: Mycotoxins in Fruits and Vegetables (Eds.: Barkai-Golan, R., Paster, N.), Elsevier, California, USA. pp.75-104.

Juan, C., Raiola, A., Manes, J., Ritieni, A., 2014. Presence of mycotoxins in commercial infant formulas and baby foods from Italian market. Food Control. 39, 227-236.

Le Bars, J., Le Bars, P., 1982. Facteurs de l'accumulation d'acide pénicillique dans les denrées d'origine végétale. Sci. Aliment. 2 (hors série II), 29-33.

Li, R., Wang, X., Zhou, T., Yang, D., Wang, Q., Zhou, Y., 2014. Occurrence of four mycotoxins in cereal and oil products in Yangtze Delta region of China and their food safety risks. Food Control. 35, 117122.

Lovelace, C.E.A., Aalbersbekg W.G.L. 1989. Aflatoxin levels in foodstuff in Fiji and Tonga Islands. Plant Foods Human Nutr. 39(4), 393-399.

Mahmoudi, M., Aryaee, P., Ghanbari, M., Ansari, H., Nourafcan, H., 2012. The determination of aflatoxin and ochratoxin of flour and wheat in Northern Iran. International Conference on Environment. Agriculture and Food Sciences (ICE-AFS'2012) Phuket (Thailand). 
Manjula, K., Hell, K., Fandohan, P., Abass, A., Bandyopadhyay, R., 2009. Aflatoxin and fumonisin contamination of cassava products and maize grain from markets in Tanzania and Republic of the Congo. Toxin Rev. 28, 63-69.

Mannon, J., Johnson, E., 1985. Fungi down on the farm. New Sci. 28, 12-16.

Molinié, A., Faucet, V., Castegnaro, M., PfohlLeszkowicz, A., 2005. Analysis of some breakfast cereals on the French market for their contents of ochratoxin A, citrinin and fumonisin B1: development of a method for simultaneous extraction of ochratoxin A and citrinin. Food Chem. 92, 391-400.

Ngundi, M.M., Shriver-Lake, L.C., Moore, M.H., Ligler, F.S., Taitt, C.R., 2006. Multiplexed detection of mycotoxins in foods with a regenerable array. J. Food Prot. 69(12), 3047-3051.

Rougerie, G., 1978. L'Encyclopédie générale de la Côte d'Ivoire: le milieu et l'histoire, Nouvelles éditions africaines, Abidjan, Paris, ISBN 2-7236-0542-6.
Se, A., Nadir, A. S., 2003. Hazard risk assessment of certain toxigenic fungion infected corn grains with special references to chemical composition and rheological properties. J. Sci. Food Agricul. 28, 6207-6219.

Shank, R.C., Vogan, G.N., Gibson, J.B., 1972. Dietary aflatoxins and human liver cancer. Toxigenic moulds in foods and foodstuffs of tropical South East Africa. Food Cosmet. Toxicol. 10(1), 51-60.

Speijers, G. J., Speijers, M. H., 2004. Combined toxic effects of mycotoxins. Toxicol. Lett. 153, 91-98.

Warth, B., Parich, A., Atehnkeng, J., Bandyopadhyay, R., Schuhmacher, R., Sulyok, M., Krska, R., 2012. Quantitation of mycotoxins in food and feed from Burkina Faso and Mozambique using a modern LCMS/MS multitoxin method. J. Agric. Food Chem. 60, 9352-9363.

Zinedine, A., and Idrissi, L., 2007. Presence et reglementation des mycotoxines dans les aliments au Maroc: Situation actuelle et perspectives. Article de synthese. Les Technol. Laborat. 7, 10-11.

\section{How to cite this article:}

Ano Guy Serge, E., N’Zue Benjamin, Y., Ade Hortense, H., Alimata, F., Karim Sory, F., Kablan, T., 2017. Mycotoxins in food: Evaluation of aflatoxin B1 and ochratoxin A in a few foodstuffs in Côte D'Ivoire. Int. J. Curr. Res. Biosci. Plant Biol. 4(11), 1-8. doi: https://doi.org/10.20546/ijcrbp.2017.411.001 